\title{
PENGARUH ALAT PERAGA TIGA DIMENSI SISTEM PEREDARAN DARAH MANUSIA TERHADAP PENINGKATAN KETERAMPILAN PROSES SAINS SISWA SMA
}

\author{
(The Effect Of Three Dimensional Tools Of Human Circulatory System To Improve The Science Process \\ Skills Of Senior High School Studentsl)
}

\section{FAHRUDDIN ARFIANTO}

\author{
Program Studi Argoteknologi Fakultas Pertanian dan Kehutanan \\ Universitas Muhammadiyah Palangkaraya \\ JI. RTA Milono Km.1,5 Palangka Raya, Kalimantan Tengah 73111 \\ e mail : fahruddin237@gmail.com
}

\begin{abstract}
This study is required by students to understand directly the circulatory system in humans with the three dimensional tools of human circulatory system. The purpose of this study was to determine the effect of three dimensional tools on science process skills of human circulatory system on circulation process material of senior high school students.

The design of this study used was pretest-posttest control group design, in this design, there were two groups selected at random, then given pretest and postes. The study was conducted at SMA Muhammadiyah 1 Palangka Raya. The period of this study was July 2014 - April 2015. The sample of the study was the students of SMA Muhammadiyah 1 Palangka Raya in XI class on the first semester, as many as two classes of experimental class and control class with the number of control class students was 29 students, experimental class was 21 students. Data collection was tested with multiple choice questions to measure students' learning outcomes, observation sheet to measure students' science process skill and using $N$ gain then analyzed by t test.

The results showed that the three dimensional tools of human circulatory system has a very significant effect on the improvement of science process skills with the most dominant indicator is in the observation. Based on the result of the study can be concluded that the use of three dimensional tools of human circulatory system can improve the science process skills of senior high school students.
\end{abstract}

Keywords: Three dimensional tools and science process skills

\section{ABSTRAK}

Penelitian ini diperlukan oleh siswa untuk belajar memahami secara langsung sistem peredaran darah pada manusia dengan alat peraga tiga dimensi sistem peredaran darah manusia. Tujuan Penelitian ini adalah untuk mengetahui pengaruh alat peraga tiga dimensi terhadap keterampilan proses sains materi sistem peredaran darah manusia pada siswa SMA.

Rancangan penelitian yang digunakan adalah pretest - postest control group design, dalam desain ini terdapat dua kelompok yang dipilih secara acak, kemudian diberi pretes dan postes. Penelitian dilaksanakan di Sekolah Menengah Umum 1 Muhammadiyah Palangka Raya. Waktu penelitian bulan Juli 2014 - April 2015. Sampel penelitian adalah siswa SMA kelas XI semester satu, sebanyak dua kelas yaitu kelas eksperimen dan kelas kontrol dengan jumlah siswa kelas kontrol 29 siswa, kelas eksperimen 21 siswa. Pengumpulan data dilakukan tes dengan bentuk soal pilihan ganda untuk mengukur hasil belajar siswa, lembar observasi untuk mengukur keterampilan proses sains siswa dan menggunakan $\mathrm{N}$ gain selanjutnya dilakukan analisis dengan uji t.

Hasil penelitian menunjukkan, bahwa alat peraga tiga dimensi sistem peredaran darah manusia berpengaruh sangat signifikan terhadap peningkatan keterampilan proses sains dengan indikator yang paling dominan adalah observasi. Berdasarkan hasil penelitian dapat ditarik kesimpulan bahwa penggunaan alat peraga tiga dimensi sistem peredaran darah manusia dapat meningkatkan keterampilan proses sains siswa SMA.

Kata kunci : Alat peraga tiga dimensi dan Keterampilan proses sains. 


\section{PENDAHULUAN}

\section{Latar Belakang}

Alat peraga atau media yang digunakan saat ini sangat banyak, baik berupa animasi maupun alat-alat peraga produksi pabrik. Alat peraga praktikum sistem peredaran darah sangat menunjang pada proses pembelajaran, namun karena adanya keterbatasan jumlah, variasi, dan kelengkapan alat peraga yang dimiliki oleh sekolah pada saat ini, maka pembelajaran belum bisa terlaksana dengan maksimal.

Alat Peraga dapat dibuat dengan sederhana hanya dengan barang-barang bekas yang banyak terdapat di sekitar kita. Belajar dengan menggunakan alat peraga akan sangat membantu siswa dalam memahami konsepkonsep yang terdapat dalam materi pembelajaran.

Media atau alat peraga yang sering digunakan dalam pembelajaran sistem peredaran darah banyak menggunakan media animasi dan memerlukan listrik, kendala yang dihadapi adalah tidak adanya aliran listrik pada sekolah yang berada jauh dari perkotaan, sehingga pelajaran sistem peredaran darah tidak bisa dilaksanakan dengan baik.

Menurut Trianto (2010) tujuan melatih keterampilan proses sains pada pembelajaran IPA yaitu meningkatkan motivasi dan hasil belajar siswa karena dapat melatih siswa dipacu untuk berpartisipasi secara aktif dan efesien dalam belajar. Keterampilan Proses Sains (KPS) dapat dimunculkan melalui penelitian ini adalah untuk mengamati, menyaksikan fakta, dan bisa mengembangkan KPS lebih meningkat dari sebelumnya, serta dapat menciptakan suatu alat peraga tiga dimensi yang lebih canggih dan bisa dipakai untuk memahami konsep sistem peredaran darah manusia secara lebih detail.

Tujuan Penelitian

Tujuan Penelitian ini adalah untuk mengetahui pengaruh alat peraga tiga dimensi terhadap keterampilan proses sains materi sistem peredaran darah manusia pada siswa SMA.

\section{Tempat dan Waktu Penelitian}

Tempat penelitian adalah Sekolah Menengah Umum 1 Muhammadiyah Palangka Raya Jalan R.T.A. Milono Km 1.5 Palangka Raya. Waktu penelitian bulan Juli 2014 - April 2015.

\section{Desain Penelitian}

Desain yang digunakan adalah pretest postest Control group Design, dalam desain ini terdapat dua kelompok yang dipilih secara acak, kemudian diberi pretes untuk mengetahui keadaan awal adalah perbedaan antara kelompok eksperimen dan kelompok kontrol (Sugiyono, 2010).

Tabel 1. Desain Penelitian

\begin{tabular}{lccc}
\hline Kelompok & Pretest & Perlakuan & Posttest \\
\hline Eksperimen & $\mathrm{O} 1$ & $\mathrm{X}_{1}$ & $\mathrm{O}_{2}$ \\
\hline Kontrol & $\mathrm{O} 1$ & $\mathrm{X}_{2}$ & $\mathrm{O}_{2}$ \\
\hline
\end{tabular}

Keterangan:

$\mathrm{O} 1$ : pretest $\mathrm{O} 2$ : postest

$\mathrm{X} 1$ : Perlakuan dengan menggunakan alat peraga tiga dimensi

X2 : Perlakuan dengan menggunakan media gambar

\section{Prosedur Penelitian}

\section{Tahap Persiapan}

Penyusunan perangkat pembelajaran, penyusunan instrument penelitian dan lembar observasi untuk keterampilan proses sains. Persiapan alat peraga tiga dimensi yaitu dengan 
pembuatan alat peraga dengan bahan-bahan sebagai berikut : gambar peredaran darah, pipa plastik, pompa minyak, lem pipa plastik, kawat bendrat dan air sumba berwarna merah. Adapun cara kerja alat peraga itu adalah sebagai berikut : ilustrasinya jika menekan pompa minyak yang ada media maka air berwarna merah akan keluar menuju aorta terus mengalir seluruh tubuh dan darah akan kembali ke jantung kembali.

\section{Tahap Pelaksanaan}

Pada tahap pelaksanaan ini merupakan tahap pengumpulan data.Data Keterampilan Proses Sains diperoleh dari observasi di dua kelas yaitu kelas kontrol dan eksperimen.

\section{Instrumen Untuk Mengukur Keterampilan Proses Sains}

Instrumen untuk parameter ini menggunakan non tes berupa lembar observasi. Instrumen ini sebelumnya sudah divalidasi oleh tim ahli. Pemberian skor $(80-100)$ berarti baik, $(60-79)$ berarti cukup baik dan $(0-59)$ berarti kurang baik

\section{Populasi dan Sampel Penelitian}

Populasi yang digunakan adalah siswa kelas XI IPA SMU Muhammadiyah 1 Palangkaraya sebanyak dua kelas dengan jumlah siswa 50 orang. Jumlah siswa yang menjadi sampel dalam penelitian ini sebanyak dua kelas yaitu kelas XI-IPA1 sebagai kelas eksperimen berjumlah 21 orang siswa dan kelas XI-IPA2 sebagai kelas kontrol berjumlah 29 orang siswa

\section{Teknik Pengumpulan Data}

\section{Pengumpulan Data Keterampilan Proses Sains}

Pengumpulan data keterampilan proses sains dilakukan dengan menggunakan lembar observasi. Setelah dilakukan penerapan alat peraga tiga dimensi terhadap keterampilan proses sains. Pengambilan data pada kelas kontrol berfungsi untuk membandingkan data pada kelas eksperimen setelah penerapan alat peraga tiga dimensi terhadap keterampilan proses sains.

\section{Teknik Analisis Data}

Data hasil belajar diperoleh dari penelitian berupa nilai pretes dan postes, baik pada kelas kontrol dan kelas eksperimen dianalisis dengan uji t. Sebelum analisis uji $t$, data pretes dan postes dilakukan analisis terlebih dahulu untuk mengetahui peningkatan dengan menggunakan rumus $\mathrm{N}$-Gain, kemudian nilai N-Gainnya yang digunakan untuk uji t.

Peningkatan hasil belajar setelah dilakukan penerapan alat peraga tiga dimensi digunakan N-gain. Gain ternormalisasi (N Gain) diperoleh dengan cara menghitung selisih antara skor tes akhir dengan tes awal yang di bagi selisih antar skor maksimal dengan skor tes awal (Meltzer, 2002).

\section{KAJIAN PUSTAKA}

\section{Alat Peraga Tiga Dimensi}

Alat peraga tiga dimensi merupakan alat peraga yang memiliki panjang, lebar dan tinggi (Sugiyono, 2010). Alat peraga tiga dimensi dapat diamati dari arah pandang mana saja dan mempunyai dimensi panjang, lebar dan tinggi/tebal dan akan sangat membantu siswa dalam memahami sistem peredaran darah manusia secara mendalam dan bermakna.

Alat peraga tiga dimensi akan meningkatkan hasil belajar menurut karmila (2002). Alat peraga tiga dimensi dikarakteristikan sebagai alat bantu lihat dengan tujuan membantu 
siswa dalam menyerap materi sistem peredaran darah manusia dan ini akan memberi manfaat kepada siswa dalam memahami serta mengerti sistem peredaran darah khususnya pada manusia.

\section{Keterampilan Proses Sains}

Keterampilan Proses Sains bisa diartikan sebagai berikut yaitu kemampuan menggunakan pikiran, nalar dan perbuatan secara efesien dan efektif untuk mencapai suatu hasil tertentu termasuk kreativitas. Keterampilan proses adalah keterampilan yang melibatkan keterampilanketerampilan kognitif atau intelektual, manual dan sosial (Rustaman, 2003). Keterampilan kognitif melibatkan pikiran, manual tentunya keterampilan menggunakan alat dan bahan, pengukuran, penyusunan atau perakitan alat untuk membuat media sederhana. Keterampilan sosial harus dimiliki oleh siswa yang berguna untuk berinteraksi dengan sesamanya dalam melaksanakan belajar dan mengajar.

Keterampilan Proses Sains adalah kemampuan siswa untuk menerapkan metode ilmiah dalam memahami, mengembangkan dan menemukan ilmu pengetahuan (Dahar, 1996).
Menurut Dimyati dan Mudjiono (2009) kelebihan KPS adalah :

1). KPS dapat memberikan rangsangan ilmu pengetahuan, sehingga siswa dapat memahami fakta dan konsep ilmu pengatahuan dengan baik

2). Memberikan kesempatan kepada siswa bekerja dengan ilmu pengetahuan, tidak sekedar menceritakan atau mendengarkan cerita tentang ilmu pengetahuan dan ini akan menjadikan siswa menjadi lebih aktif

3) Siswa dapat belajar proses dan produk ilmu pengetahuan

Proses sains merujuk pada proses mental yang terlibat ketika menjawab suatu pertanyaan atau memecahkan masalah, seperti mengidentifikasi dan menginterpretasi bukti serta menerangkan kesimpulan (Rustaman dkk, 2005). Sains sebagai proses akan selalu merujuk pada suatu aktivitas ilmiah yang dilaksanakan oleh para ahli sains. Setiap aktivitas ilmiah memiliki ciri-ciri yang rasional, kognitif dan bertujuan (Toharudin $d k k, 2011)$

Rustaman dkk (2005) memaparkan indikator keterampilan proses sains seperti tertera pada Tabel 2.

Tabel 2. Indikator keterampilan proses sains

\begin{tabular}{|c|c|}
\hline $\begin{array}{c}\text { Indikator Keterampilan } \\
\text { Proses Sains } \\
\end{array}$ & Karakteristik \\
\hline $\begin{array}{ll}\text { 1. Observasi } \\
\text { (pengamatan) }\end{array}$ & $\begin{array}{l}\text { - Menggunakan indera penglihatan, pembau, } \\
\text { pendengaran, pengecap dan peraba } \\
\text { - Menggunakan fakta yang relevan dan memadai }\end{array}$ \\
\hline $\begin{array}{ll}\text { 2. } & \text { Interpretasi } \\
& \text { (Menafsirkan) }\end{array}$ & $\begin{array}{l}\text { - Menghubungkan hasil pengamatan } \\
\text { - Menentukan pola atau keteraturan dari suatu seri } \\
\text { pengamatan } \\
\text { - Menyimpulkan }\end{array}$ \\
\hline
\end{tabular}




\begin{tabular}{|c|c|c|}
\hline & $\begin{array}{l}\text { Klasifikasi } \\
\text { (mengelompokkan) }\end{array}$ & $\begin{array}{l}\text { - Mencatat setiap hasil pengamatan secara terpisah } \\
\text { - Mencari perbedaaan } \\
\text { - Mengkontraskan ciri-ciri } \\
\text { - Mencari kesamaan } \\
\text { - Membandingkan } \\
\text { - Mencari dasar penggolongan atau pola yang sudah } \\
\text { ada }\end{array}$ \\
\hline 4. & Prediksi (meramalkan) & $\begin{array}{l}\text { - Menggunakan pola atau keteraturan hasil } \\
\text { pengamatan } \\
\text { - Mengajukan perkiraan tentang sesuatu yang belum } \\
\text { terjadi bedasarkan suatu kecendrungan }\end{array}$ \\
\hline 5. & Berk & $\begin{array}{l}\text { - Membaca grafik, tabel atau diagram } \\
\text { - Menjelaskan hasil percobaan } \\
\text { - Menyusun dan menyampaikan laporan secara } \\
\text { sistematik dan jelas } \\
\text { - Mendiskusikan hasil kegiatan suatu masalah atau } \\
\text { suatu peristiwa }\end{array}$ \\
\hline 6. & $\begin{array}{l}\text { Mens } \\
\text { perta }\end{array}$ & $\begin{array}{l}\text { - Pertanyaan yang diajukan dapat meminta penjelasan } \\
\text { tentang apa, mengapa, bagaimana, ataupun } \\
\text { menanyakan latar belakang hipotesis. }\end{array}$ \\
\hline 7. & Berhi & $\begin{array}{l}\text { - Menyatakan hubungan dua variabel atau } \\
\text { memperkirakan penyebab sesuatu terjadi } \\
\text { - Menyadari bahwa satu penjelasan perlu diuji } \\
\text { kebenarannya dengan memperoleh bukti lebih banyak } \\
\text { atau melakukan cara pemecahan masalah }\end{array}$ \\
\hline 8. & $\begin{array}{l}\text { Mere } \\
\text { perco } \\
\mathrm{n}\end{array}$ & $\begin{array}{l}\text { - Menentukan alat dan bahan atau sumber yang } \\
\text { - Migunakan } \\
\text { - Menentukan variabel atau faktor penentu } \\
\text { - Menentukan variabel control atau variabel bebas } \\
\text { - Menentukan apa yang diamati, diukur atau ditulis } \\
\text { - Menentukan cara dan langkah kerja } \\
\text { - Mengolah data }\end{array}$ \\
\hline 9. & $\begin{array}{l}\mathrm{M} \epsilon \\
\mathrm{ko}\end{array}$ & $\begin{array}{l}\text { - Menjelaskan suatu peristiwa dengan menggunakan } \\
\text { konsep yang telah dimiliki } \\
\text { - Menerapkan konsep yang telah dipelajari dalam } \\
\text { situasi baru }\end{array}$ \\
\hline
\end{tabular}

\section{Sistem Peredaran Darah}

Sistem peredaran darah pada manusia termasuk sistem peredaran darah tertutup artinya darah mengalir melalui pembuluh darah. Sistem peredaran darah pada manusia juga disebut sistem peredaran darah rangkap dimana darah melewati jantung sebanyak dua kali. Peredaran darah dari jantung menuju paru-paru dan kembali ke jantung disebut peredaran darah kecil. Darah beredar dari jantung ke seluruh tubuh dan kembali ke jantung disebut peredaran darah besar (Omegawati dan Kusumawati, 2010). Sistem peredaran pada manusia tersusun atas darah, pembuluh darah dan jantung sebagai pusat peredaran darah (Pratiwi $d k k$, 2007). Omegawati dan Kusumawati, 2010 memaparkan bahwa sistem peredaran darah mempunyai fungsi sebagai berikut : 
1). Mengangkut zat makanan dan sisa hasil HASIL DAN PEMBAHASAN metabolisme

2). Mengangkut zat buangan dan substansi beracun menuju hati untuk dinetralkan

3). Mengangkut zat buangan dan substansi beracun menuju ginjal untuk dibuang

4). Mendistribusikan hormon dari kalenjar dan organ yang memproduksinya ke sel-sel tubuh yang membutuhkan

5). Mengatur suhu tubuh melalui aliran darah

6). Mencegah hilangnya darah melalui mekanisme pembekuan darah

7). Melindungi tubuh dari bakteri dan virus dengan mensirkulasikan antibodi dan sel darah putih.

\begin{abstract}
Data Keterampilan Proses Sains
Data keterampilan proses sains siswa diperoleh dengan menggunakan lembar observasi dan dilihat setiap indikator. Observasi terdiri dari 9 indikator yang di amati. Hasil observasi menunjukkan perbedaan keterampilan proses sains skor antara kelas eksperimen dan kelas kontrol. Skor siswa dan rerata keterampilan proses sains pada kelas eksperimen dan kelas kontrol dapat dilihat di tabel 3 .
\end{abstract}

Tabel 3. Skor dan Rerata Beda Tiap Indikator Keterampilan Proses Sains

\begin{tabular}{lllll}
\hline \multicolumn{1}{c}{ Indikator } & \multicolumn{1}{c}{ Skor } & & Rerata & Kategori \\
\hline \multirow{2}{*}{ Observasi (pengamatan) } & Kelas Eksperimen & 1500 & 71,4 & Baik \\
\cline { 2 - 5 } & Kelas Kontrol & 1435 & 49,5 & Jelek \\
\hline Interpretasi (Menafsirkan) & Kelas Eksperimen & 1367 & 65,1 & Baik \\
\cline { 2 - 5 } & Kelas Kontrol & 1593 & 54,9 & Baik \\
\hline Klasifikasi (mengelompokkan) & Kelas Eksperimen & 1220 & 58,1 & Baik \\
& Kelas Kontrol & 1213 & 41,9 & Jelek \\
\hline Prediksi (meramalkan) & Kelas Eksperimen & 1285 & 61,2 & Baik \\
\cline { 2 - 5 } & Kelas Kontrol & 1373 & 47,3 & Jelek \\
\hline Berkomunikasi & Kelas Eksperimen & 1290 & 61,4 & Baik \\
\cline { 2 - 5 } & Kelas Kontrol & 1383 & 47,7 & Jelek \\
& & & & \\
\hline Mengajukan pertanyaan & Kelas Eksperimen & 1470 & 69,5 & Baik \\
\cline { 2 - 5 } & Kelas Kontrol & 1386 & 47,6 & Jelek \\
& & & & \\
\hline Berhipotesis & Kelas Eksperimen & 1115 & 53,1 & Baik \\
\cline { 2 - 5 } & Kelas Kontrol & 1505 & 51,9 & Baik \\
& & & & \\
\hline Merencanakan & & & \\
percobaan/penyelidikan & Kelas Eksperimen & 1280 & 61,0 & Baik \\
\hline Melas Kontrol & 1505 & 51,9 & Baik \\
\hline & Kelas Eksperimen & 1165 & 55,5 & Baik \\
\cline { 2 - 5 } & Kelas Kontrol & 1525 & 52,6 & Baik \\
\hline
\end{tabular}


Grafik Skor Indikator KPS Kelas Eksperimen dan Kontrol

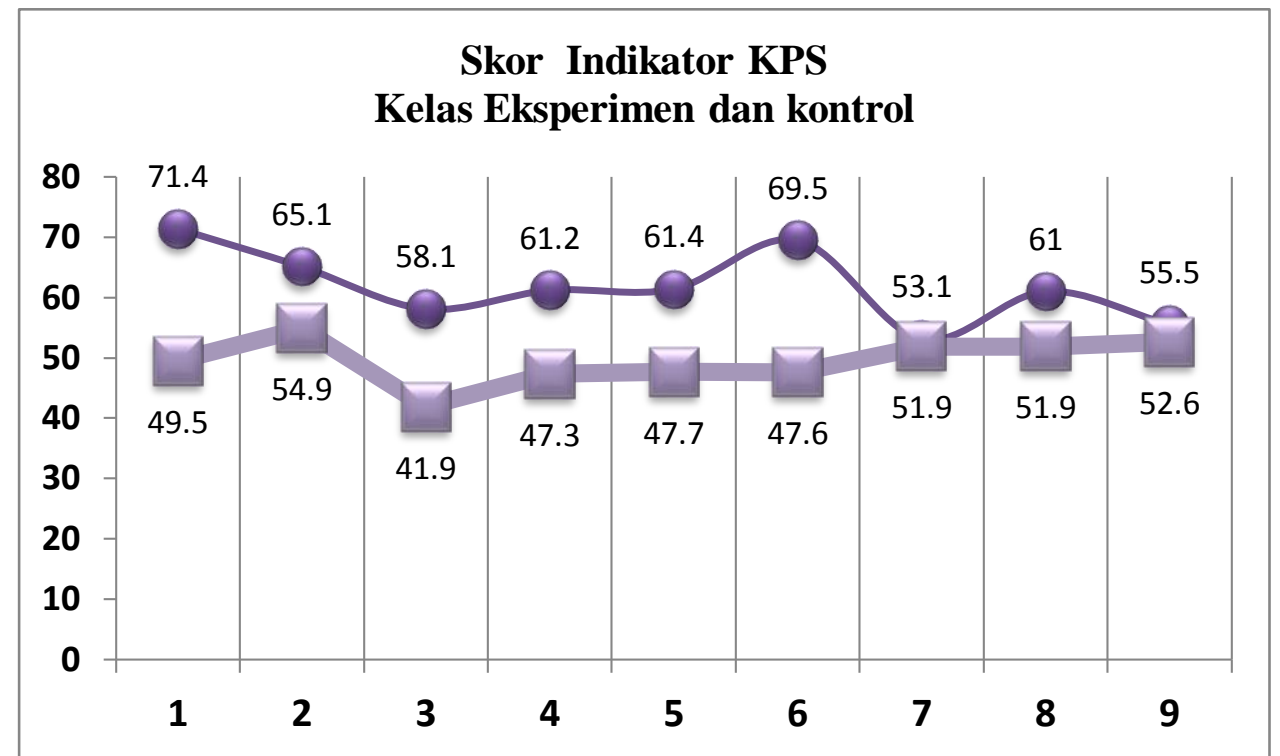

Tabel 4. Total Skor Siswa dan Rerata Keterampilan Proses Sains

\begin{tabular}{lccrrc}
\hline Perlakuan & Jumlah siswa & Skor siswa & Rerata & Std.Dev & Kategori \\
\hline Kelas eksperimen & 21 & 11692 & $61,9 \pm$ & 7,799 & Baik \\
\hline Kelas kontrol & 29 & 12914 & $49,5 \pm$ & 4,642 & Jelek \\
\hline
\end{tabular}

Berdasarkan tabel 3. Tiap indikator mempunyai skor nilai yang berbeda-beda dari kedua kelas, nilai skor keterampilan proses sains kelas eksperimen lebih tinggi daripada kelas kontrol. Nilai rerata skor indikator keterampilan proses sains tertinggi pada kelas eksperimen terdapat pada indikator observasi (pengamatan) dan nilai rerata skor indikator keterampilan proses sains terendah terdapat pada indikator berhipotesis. Pada kelas kontrol nilai rerata yang tertinggi ada pada indikator interprestasi (menafsirkan) dan yang terendah pada indikator berhipotesis dapat dilihat dari grafik 1.

Berdasarkan tabel 4. Total skor dan rerata keterampilan proses sains pada kelas eksperimen menunjukkan nilai yang tinggi daripada nilai total skor dan rerata pada kelas kontrol. Tabel 4 memperlihatkan bahwa keterampilan proses sains sudah mulai berkembang dengan kategori baik.

\section{PEMBAHASAN}

\section{Pengaruh Alat Peraga Tiga Dimensi Terhadap Keterampilan Proses Sains Siswa}

Berdasarkan hasil observasi skor rerata nilai keterampilan proses sains pada materi sistem peredaran darah manusia, kelas yang menggunakan alat peraga tiga dimensi sistem peredaran darah manusia lebih tinggi daripada kelas yang tidak menggunakan alat peraga tiga dimensi. Pada indikator-indikator yang 
ditampilkan dalam grafik Skor Indikator KPS Kelas Eksperimen dan Kontrol. keterampilan proses sains yang dominan adalah indikator observasi (pengamatan) pada kelas eksperimen dimana pada indikator ini siswa akan merasakan secara langsung dan mengamati bagaimana cara kerja sistem peredaran darah manusia yang selama ini tidak siswa dapatkan secara kongkrit atau nyata. Menurut Listyaningrum dkk (2012), penerapan pembelajaran berbasis keterampilan proses sains mampu meningkatkan sikap ilmiah siswa, siswa lebih berani menyampaikan pendapatnya baik dalam kelompok maupun dalam kelas.

\section{KESIMPULAN DAN SARAN}

\section{Kesimpulan}

Berdasarkan hasil analisis data dan hasil pembahasan penelitian ini dapat ditarik kesimpulan Keterampilan proses sains siswa meningkat pada materi sistem peredaran darah dengan menggunakan alat peraga tiga dimensi. Perkembangan siswa terhadap keterampilan proses sains dikategorikan baik bila dibandingkan dengan kelas yang tidak menggunakan alat peraga tiga dimensi. Alat peraga tiga dimensi memberi pangaruh yang baik sehingga keterampilan proses sains berkembang walaupun dengan kategori baik.

\section{Saran}

Berdasarkan hasil analisis data dan hasil pembahasan penelitian penulis menyarankan sebagai berikut :

1) Penelitian ini masih banyak kekurangan maka perlu diadakan penelitian lanjutan sehingga penelitian dengan alat peraga tiga dimensi akan lebih berkembang lagi.
2) Keterampilan proses sains sangat perlu dikembangkan ditiap-tiap sekolah baik dipelosok maupun diperkotaan, sehingga dapat mengasah daya kreativitas siswa dalam mencipta. Dalam hal ini diperlukan penelitian lanjutan mengenai keterampilan proses sains terhadap siswa didik.

\section{DAFTAR PUSTAKA}

Dimyati dan Mudjiono, 2002, Belajar dan Pembelajaran, Rineka Cipta, Jakarta.

Dimyati dan Mudjiono, 2009, Belajar dan Pembelajaran, Rineka Cipta, Jakarta.

Karmila, Penggunaan Alat Peraga Visual Tiga Dimensi Untuk Meningkatkan Hasil Belajar IPA Siswa Kelas IV SDN 2 Jatisela Tahun Ajaran 2012/2013,http://fkipunram.ac.id/ejurnal/ index.php/pgsd/article/view/146, diakses 5 Maret 2014.

Listyaningrum R.I., Sajidan dan Suciati, 2012, Penerapan Model Pembelajaran Inductive Thinking Berbasis Keterampilan Proses Sains untuk Meningkatkan Kualitas Pembelajaran Biologi Siswa Kelas X.7 SMA Negeri 2 Karanganyar Tahun pelajaran 2011/2012, Jurnal Pendidikan Biologi Volume 4 Nomor 1 UNS, http://www.jurnal.fkip.uns.ac.id/index.ph p/bio/article/view/1405/986 , diakses 22 Maret 2015

Rustaman, N.Y., 2003, Strategi Belajar Mengajar Biologi, Jurusan Pendidikan Biologi FPMIPA UPI, Bandung.

Rustaman, N.Y, S. Dirdjosoemarto, S.A.Yudianto, M.N.Kusumastuti, Rochintaniawati., D. Achmad. 2005. Strategi Belajar Mengajar Biologi. Malang. UM Press : Malang.

Sugiyono, 2010. Metode Penelitian Kuantitatif Kualitatif dan R\&D, Alfabeta 
Omegawati, W.H dan Kusumawati, R. 2010. Buku Panduan Pendidik Biologi Untuk SMA/MA. Intan Pariwara. Klaten

Pratiwi, D.A., Maryati, S., Srikini. Suharno dan Bambang. 2007. Biologi untuk SMA kelas XI. Erlangga. Jakarta.

Trianto. 2010. Model Pembelajaran Terpadu. Surabaya: Bumi Aksara. 